\title{
Between Centralized Federalism and Regionalized Centralism - Introduction to the Special Issue on Latin American Constitutionalism
}

\author{
By Axel Tschentscher* and Andreas Gutmann**
}

I. Constitutional Law in Latin America is increasingly attracting the attention of comparative scholarship. While most literature tends to focus on individual rights rather than institutional settings, adequate institutions are an indispensable prerequisite to effectively realize constitutional goals. They are the "engine room" (Gargarella) of constitutional functions and, therefore, an important factor sometimes neglected by Latin American constitutionalism. The extent to which political power is decentralized belongs to the institutional properties that have an impact on the constitutional agenda at large.

The articles in this special issue focus on structural aspects of constitutionalism in Latin America triggered by the general trend towards regional autonomy and, in some countries, towards federalism. Since the last decades of the $20^{\text {th }}$ century we have observed a distinct tendency towards decentralization in Latin American countries. Central governments delegate power to territorial entities. Elections are held to designate local authorities. New or drastically modified entities arise, such as autonomous indigenous territories or metropolises holding a special status within the state. The contributions of this special issue are all casting a critical light on the promises commonly associated with the decentralization process - the promise to foster participation, to improve democratic legitimacy, to achieve peace, to gain political stability, and, thereby, to create an institutional setting favorable of constitutional rights.

Debates about decentralization, federalism, and centralization did not only arise in the $20^{\text {th }}$ century. They have a long tradition within the Latin American context. Even the IncaEmpire was known for its sophisticated territorial structure. It consisted of four regions (suyos) as well as numerous subdivisions (wamani and saya) and might therefore be considered an early decentralist system. Also, the dispute between the Libertador Simón Bolivar and Francisco de Paula Santander about federalizing or centralizing postcolonial Colombia is still of interest today.

The historical and contemporary focus on decentralization has one of its roots in the large territorial scope of many Latin American countries. They include sparsely populated and remote areas that pose a severe challenge to territorial organization. Latin American constitutions respond to this challenge in different ways. Most recently, they started to grant special legal status to metropolises like Mexico-City that became distrito federaI in 2016.

* Professor at the University of Bern, Institute for Public Law, Chair for Constitutional Law, Legal Philosophy and Constitutional History.

** Research Assistant at the University of Bern, Institute for Public Law. 
By doing so, the states react to the concentration of population, economic power, as well as sociocultural and educational facilities within the respective capitals. Even earlier, the constitutions started to cede powers to sub-state entities in order to better reach remote areas and to extend political power to all parts of the country. As the articles of this special issue illustrate, decentralization does not only foster regional autonomy and self determination, but also demonstrates the central state's will to effective rule.

Among the general issues of decentralization belongs the marginalization of indigenous and rural groups. Some of them are living at very large distances from the capital and in places where state power is almost absent. They remain a governance problem in many Latin American countries. Strengthening sub-state entities might help to include such groups into the overall system of legitimate government. However, this strategy faces serious challenges, as the articles of this special issue show. Sub-state entities are threatened both by private actors and by central government entities jealous of decentralized competences. The authors of this special issue provide several proposals how the law might face these drawbacks of decentralization.

II. Motivated by the effects of institutional constitutionalism, recent research has tried to determine how systemic decentralization actually works. While often appreciated as a measure to promote democratic participation, it turns out to be quite difficult to achieve progress by empowering sub-state entities. Against the background of progressive and restrictive moves, this special issue contains four articles covering a diverse range of perspectives on decentralization:

1. In the first article, Maria Bertel casts doubt on the thesis that decentralization per se improves democratic participation on a qualitative level. By investigating the Peruvian model, she notes that the process of decentralization might also increase clientelism, populism, and corruption. A successful and therefore participatory decentralization process depends on an adequate set of electoral rules. This is of utmost importance in the Peruvian case where political parties lack constancy and weight, Bertel argues. Examining recent reforms of electoral law, she is rather pessimistic about expanding democratic participation by means of decentralization.

2. Regarding the comparative evolution of federalism in Latin America, Enrique Rabell Garcia takes a close look at the current varieties. By using a multidisciplinary approach, he determines the federal symmetry ("understood as equality among federal states and local governments", p. 33) of Argentina, Brazil, and Mexico. With data from different fields he is able to measure the degree of symmetry and therefore directly compare these countries. Rabell Garcia states that symmetric federalism tends to be more stable then asymmetric federalism. He exemplifies the relevance of this thesis by graphic depictions analyzing his findings.

3. Like many countries in the region, centralist Colombia initiated a process of decentralization in the 1980s. By looking at this process, Julián Arévalo Bencardino, David A. Ortiz Escobar and Andrea García Albarracín observe that democratic participation has 
significantly increased on a subnational level. Nevertheless, autonomy of the subnational entities stands on shaky grounds. It can easily be modified by the national government which leads to a "re-centralization trajectory" (p. 60). This is most evident in fiscal issues. The authors are convinced that political, fiscal, and administrative decentralization will foster public participation and stability, thereby echoing Rabell Garcia's thesis concerning symmetry within federal states. They emphasize how important the concept of territorial peace is that can be found in the peace agreement with the FARC. Therefore, they are in favor of stopping the ongoing re-centralization and reinforcing the original process of decentralization.

4. Decentralization as a tool of emancipation for marginalized groups is discussed in the final article by Franziska Englert and Jonathan Schaub-Englert. They present "indigenous territorial autonomies" (AIOCs) in Bolivia as a pillar of the ambitious decolonization agenda pursued by the constitution. These communities form territorial entities sui generis within the Bolivian state. That is why their autonomy and competences are "inherently subordinated to the national State" (p. 78). This and other challenges for indigenous self-determination promoted by decentralization are identified by Englert and Schaub-Englert. Therefore, they might agree with Bertel that decentralization of centralist states is not by itself a panacea for strengthening participation and political empowerment, but needs adequate criteria and procedures in order to fulfill the prevalent expectations. 